EMILIA KLICH

Uniwersytet Wrocławski

Instytut Informacji Naukowej i Bibliotekoznawstwa

\title{
ZAANGAŻOWANIE INSTYTUCJI NAUKI I KULTURY W ROZWÓJ POLSKIEJ BIOGRAFISTYKI KSIĘGOZNAWCZEJ
}

Historia i współczesność instytucji zaangażowanych w rozwój polskiej biografistyki księgoznawczej stanowi bardzo ciekawy materiał badawczy. W artykule szczególny nacisk położono na instytucje zaangażowane $\mathrm{w}$ tworzenie oraz rozwój polskich informatorów biograficznych i biografii zbiorowych, dotyczących ludzi książki. Nie zawsze badania biograficzne są statutowym celem tych organizacji, mimo to często biorą one udział w działaniach i projektach mających na celu zachowanie pamięci o ludziach zaangażowanych w kulturę książki w Polsce. Ukazane tutaj dzieje obejmują okres powojenny do początków XXI wieku. Źródłem danych stała się, stworzona dla celów rozprawy doktorskiej, baza danych polskich informatorów biograficznych i biografii zbiorowych wydanych w Polsce w XX i na początku XXI wieku. Z niej pochodzi korpus informatorów, które poddane zostaną analizie.

Od czasów wojny do dziś ukazało się około sześćdziesięciu różnorodnych informatorów biograficznych i biografii zbiorowych dotyczących ludzi książki. Jedynie w powstanie części z nich zaangażowane są instytucje. Mają one różnorodny zasięg terytorialny: od informatorów, dotyczących całego kraju, poprzez regionalne i lokalne. Informatory narodowe dotyczące ludzi książki, takie jak: Słownik pracowników książki polskiej oraz Drukarze dawnej Polski, to uznane już dzieła, bardzo ważne w rozwoju biografistyki 
księgoznawczej. Nie mniej ważne, a nawet ważniejsze dla środowisk lokalnych i regionalnych są informatory o charakterze regionalnym i lokalnym. Na poziomie regionalnym dotyczą one Małopolski, Mazowsza, Pomorza, Śląska, Wielkopolski czy Ziemi Lubartowskiej; lokalne zaś zawierają biogramy ludzi książki z Częstochowy, Lublina, Opola, Płocka, Śremu, Warszawy czy Wrocławia. Dzięki tym wydawnictwom poznajemy ludzi działających w środowisku lokalnym, których często próżno szukać w wydawnictwach o zasięgu narodowym czy międzynarodowym.

Analizę informatorów biograficznych i biografii zbiorowych należy rozpocząć od dwóch monumentalnych publikacji i instytucji, które zainicjowały i uczestniczyły w powstaniu: Słownika pracowników książki polskiej oraz Drukarzy dawnej Polski.

\section{Słownik pracowników książki polskiej}

Tworzony był w ośrodku, który od lat uważany jest za centrum biografistyki księgoznawczej - łódzki ośrodek bibliotekoznawczy. Badania biograficzne ludzi książki, prowadzone w ramach tego projektu, przyczyniły się do rozwoju bibliologii. Spełnia on bowiem założenia dotyczące zadań specjalnych słowników biograficznych, których głównym celem jest zebranie i przedstawienie życiorysów osób zaangażowanych w rozwój konkretnej dziedziny życia czy nauki ${ }^{1}$.

Geneza powstania tego informatora sięga lat wojny. Początek prac związany jest z Biblioteką Zamoyskich, gdzie stworzono i zaczęto gromadzić kartotekę bibliograficzną. Następnie w 1946 roku prace przejął Państwowy Instytut Książki, kierowany przez Adama Łysakowskiego. Bardzo ambitne plany dotyczyły uwzględnienia wszystkich najwybitniejszych i najbardziej zasłużonych osób, które na przestrzeni dziejów Polski były związane z wytwarzaniem i rozpowszechnianiem książki². Pierwotny projekt, prowadzony przez Wiesława Mincera, nie zakładał szczegółowego opracowywania poszczególnych biogramów, a jedynie zgromadzenie krótkich biograficznych danych wraz z piśmiennictwem o danych osobach ${ }^{3}$. Zebraną kartotekę biobibliograficzną, po likwidacji PIK w 1949 roku, przeniesiono do Biblioteki Uniwersyteckiej w Toruniu, która kontynuowała prace nad nią

\footnotetext{
${ }^{1}$ I. Homola, Międzynarodowe i narodowe słowniki biograficzne, „Kwartalnik Historyczny” 1957, nr 3, s. 233-235.

2 J. Korpała, Słownik pracowników książki polskiej, „Przegląd Biblioteczny” 1975, z. 2, s. 196.

3 M. Korczyńska-Derkacz, Państwowy Instytut Książki (1946-1949) i jego rola w rozwoju bibliologii, bibliotekarstwa i kultury książki w Polsce, Wrocław 2011, s. 194.
} 
zgodnie z wcześniejszymi zasadami. W tym czasie kilka jednostek w kraju prowadziło badania z zakresu biografii ludzi książki. W Bibliotece Uniwersyteckiej w Łodzi prowadzono prace $\mathrm{z}$ wykorzystaniem podobnych metod, co jedynie potwierdziło dobry kierunek badań, gdyż zbliżone założenia wypracowały dwa niezależne od siebie ośrodki, które ostatecznie w latach 1952-1953 nawiązały współpracę. Analogiczne badania zapoczątkowały Biblioteka Jagiellońska oraz Biblioteka Uniwersytecka we Wrocławiu. Dopiero w 1954 roku Komisji do spraw bibliotek Rady Głównej Szkolnictwa Wyższego udało się skoordynować badania prowadzone w kilku ośrodkach jednocześnie ${ }^{4}$. Dzięki temu prace nad Słownikiem prowadzone były przez kilka bibliotek uniwersyteckich (dołączyły do nich Biblioteka Ossolineum, Biblioteka Gdańska PAN i Książnica Miejska im. Kopernika w Toruniu).

Pierwszym redaktorem słownika był Ksawery Świerkowski - to pod jego redakcją ukazał się w 1958 roku Zeszyt próbny ${ }^{5}$, wydany z zasiłku Ministerstwa Szkolnictwa Wyższego. Po jego rezygnacji od 1961 roku redaktorem naczelnym była Irena Treichel, która została redaktorem zarówno Słowni$k a^{6}$, jak i Suplementu ${ }^{7}$.

W pracach nad tym monumentalnym dziełem uczestniczył również Wrocław. W latach 1977-1979 prace nad Słownikiem zostały umieszczone w planie prac naukowych Instytutu Bibliotekoznawstwa Uniwersytetu Wrocławskiego. Zostały sklasyfikowane w obszarze zadania badawczego Zawód bibliotekarza $w$ PRL, prowadzonego przez Instytut pod kierunkiem dr Zofii Gacy-Dąbrowskiej w ramach problemu węzłowego: Polska kultura narodowa, jej tendencje rozwojowe i percepcja. Za to zaangażowanie Irena Treichel dziękowała na łamach "Przeglądu Bibliotecznego" ${ }^{8}$ oraz redakcji Suplemen$t u$ we wstępie do informatora. Szczególne podziękowania kierowane były do prof. Bronisława Kocowskiego, ówczesnego dyrektora Instytutu za rozumienie potrzeb kontynuacji prac nad Słownikiem ${ }^{9}$.

$\mathrm{W}$ trakcie prac zawiązała się współpraca $\mathrm{z}$ szeregiem instytucji m.in.: bibliotekami akademickimi i naukowymi, archiwami i muzeami regional-

${ }^{4}$ W. Mincer, Informacja o Słowniku Biograficznym Pracowników Książki Polskiej, „Zeszyty Naukowe Uniwersytetu Mikołaja Kopernika w Toruniu. Nauki Humanistyczno-Społeczne, z. 18, „Nauka o Książce” 1966, nr 4, s. 66.

${ }^{5}$ Słownik biograficzny pracowników książki polskiej. Zeszyt próbny, red. K. Świerkowski, Łódź 1958.

${ }^{6}$ Słownik pracowników książki polskiej, red. I. Treichel, Łódź 1972.

7 Słownik pracowników książki polskiej. Suplement, red. I. Treichel, Łódź 1986.

${ }^{8}$ I. Treichel, Suplement do „Słownika pracowników książki polskiej”, „Przegląd Biblioteczny” 1979, nr 3, s. 331-332.

9 Słownik pracowników książki polskiej. Suplement..., s. 8. 
nymi, katedrami bibliotekoznawstwa, Instytutem Sztuki PAN, zespołem współpracowników Drukarzy dawnej Polski, Komisją Historyczną Stowarzyszenia Księgarzy Polskich, Zakładem Historii Partii przy KC PZPR oraz indywidualnymi autorami. Kontakty te wykorzystywane były nie tylko w pracach nad Słownikiem, ale służyły również redakcji powstającej w tym okresie Encyklopedii Wiedzy o Książe ${ }^{10}$.

W 1992 roku powołana została Pracownia Słownika pracowników książki polskiej przy Katedrze Bibliotekoznawstwa i Informacji Naukowej Uniwersytetu Łódzkiego, która pod redakcją Hanny Tadeusiewicz przejęła prace nad Słownikiem. Jednocześnie badania nad biografistyką księgoznawczą zostały określone jako główny kierunek dociekań naukowych, który wyróżnił Pracownię Słownika wśród innych instytucji o podobnym charakterze ${ }^{11}$. Pod redakcją Hanny Tadeusiewicz ukazał się w 2000 roku Suplement $I I^{12}$, a w 2010 Suplement III ${ }^{13}$. Należy dodać, że zarówno Suplement II oraz Suplement III ukazały się w Wydawnictwie SBP w serii Nauka, Dydaktyka, Praktyka. W 2010 roku kierownictwo pracownią objęła Magdalena Rzadkowolska. Od 2011 roku, po zdobyciu grantu Narodowego Programu Rozwoju Humanistyki, trwają prace nad Suplementem IV.

\section{Drukarze dawnej Polski}

Kolejne monumentalne dzieło to, ukazujące się od 1959 roku, Drukarze dawnej Polski od XV do XVIII wieku. Jest ono nieocenioną pomocą w badaniach nad dziejami kultury polskiej w XV-XVIII wieku. Od początku projekt zakładał ambitny plan badawczy. Nie zawsze jednak udawało się realizować zaplanowane zadania i dotrzymywać terminów wydań poszczególnych tomów. Dzieło to zapoczątkowała Alodia Kawecka-Gryczowa - pod jej redakcją i kierunkiem ukazała się część tomów. Z zaplanowanych początkowo sześciu zeszytów powstało dzieło, obejmujące dotychczas cztery obszerne tomy. Wszystkie oparte były na materiałach z Pracowni Bibliografii Staropolskiej IBL PAN. Tomy wydane w 2000 roku ukazały się pod redakcją Jana Pirożyńskiego, a ostatni tom, wydany w 2001 roku, redagowała Krystyna

\footnotetext{
${ }^{10}$ I. Treichel, Słownik pracowników książki polskiej: przebieg prac nad realizacją publikacji, ich organizacja i metody, „Przegląd Biblioteczny” 1985, nr 3/4, s. 442.

${ }_{11}$ Z. Gaca-Dąbrowska, Słownik pracowników książki polskiej, „Roczniki Biblioteczne” R. 45, 2001, s. 278.

${ }_{12}$ Słownik pracowników książki polskiej. Suplement 2, red. H. Tadeusiewicz, B. Karkowski, Warszawa 2000.

${ }^{13}$ Stownik pracowników książki polskiej. Suplement 3, red. H. Tadeusiewicz, Warszawa 2010.
} 
Korotajowa. W poszczególnych tomach przedstawiono drukarnie $\mathrm{z}$ terenu Małopolski ${ }^{14}$, Wielkopolski ${ }^{15}$, Pomorza ${ }^{16}$, Wielkiego Księstwa Litewskiego ${ }^{17}$, Małopolski - Ziemie Ruskie ${ }^{18}$ oraz Mazowsza z Podlasiem ${ }^{19}$. Od lat publikacja cieszy się niezwykłym zainteresowaniem, a poszczególne tomy przybliżają nam kolejnych właścicieli drukarń, czeladników, uczniów oraz odlewników czcionek. Warte wspomnienia są, oprócz haseł biograficznych, hasła topograficzne, które szczegółowo charakteryzują polskie oficyny drukarskie na przestrzeni XV-XVIII wieku.

Początkowo wydawcą słownika był Zakład Narodowy im. Ossolińskich, następnie Polska Akademia Umiejętności oraz ostatecznie Instytut Badań Literackich PAN. Instytut powstał w 1948 roku, podlegając jako samodzielna placówka naukowo-badawcza, najpierw Ministerstwu Oświaty, później Ministerstwu Szkół Wyższych i Nauki. Jako pierwsza placówka Wydziału Nauk Społecznych, został włączony w 1952 roku w strukturę Polskiej Akademii Nauk. Od początku istnienia instytut zaangażowany jest w rozwój biobibliografii, do dziś wykorzystywane są gromadzone tam materiały źródłowe oraz różnorodne kartoteki, które stanowią wspaniałą bazę dla kolejnych ważnych publikacji ${ }^{20}$.

Ostatni tom ukazał się przy wsparciu Stowarzyszenia „Pro kultura litteraria”. Stowarzyszenie to istnieje od 1994 roku. Założyli je pracownicy Instytutu Badań Literackich PAN w celu wspierania polonistycznej działalności naukowej, wydawniczej i popularyzatorskiej ${ }^{21}$. Wszystkie tomy ukazują się

${ }^{14}$ Drukarze dawnej Polski od XV do XVIII wieku: praca zbiorowa. t. 1, Małopolska.cz. 1, Wiek XVI-XVI, red. A. Kawecka-Gryczowa, Wrocław 1983; Drukarze dawnej Polski od XV do XVIII wieku: praca zbiorowa. t. 1, Małopolska. cz. 2, Wiek XVII-XVIII. Vol. 1, A-K. red. J. Pirożyński, Kraków 2000; Drukarze dawnej Polski od XV do XVIII wieku: praca zbiorowa. t. 1, Małopolska. cz. 2, Wiek XVII-XVIII. Vol. 2, L-Ż i drukarnie żydowskie, red. J. Pirożyński, Kraków 2000.

${ }^{15}$ Drukarze dawnej Polski od XV do XVIII wieku. t. 3 cz. 1, Wielkopolska, oprac. A. Kawecka-Gryczowa, K. Korotajowa, J. Sójka, Wrocław 1977.

${ }^{16}$ Drukarze dawnej Polski od XV do XVIII wieku. t. 4, Pomorze, oprac. A. Kawecka-Gryczowa, K. Korotajowa, Wrocław 1962.

${ }_{17}$ Drukarze dawnej Polski od XV do XVIII wieku. z. 5, Wielkie Księstwo Litewskie. oprac. A. Kawecka-Gryczowa, K. Korotajowa, W. Krajewski, Wrocław 1959.

${ }_{18}$ Drukarze dawnej Polski od XV do XVIII wieku. z. 6, Małopolska - Ziemie Ruskie oprac. A. Kawecka-Gryczowa, K. Korotajowa, W. Krajewski, oprac., Wrocław 1960.

${ }^{19}$ Drukarze dawnej Polski od XV do XVIII wieku. t. 3 cz. 2, Mazowsze z Podlasiem, red. K. Korotajowa, J. Krauze-Karpińska, Warszawa 2001.

${ }^{20}$ E. Sarnowska-Temeriusz, Słowo wstępne [w:] Instytut Badań Literackich Polskiej Akademii Nauk 1948-2001, red. J. Czachowska, Warszawa 2002.

${ }^{21}$ Stowarzyszenie „Pro kultura litteraria” [w:] Instytut Badań Literackich PAN [online]. [dostęp: 29.05.2013]. Dostępny WWW: http://ibl.waw.pl/pl/stowarzyszenie-pro-cultura-litteraria 
w serii Książka w Dawnej Kulturze Polskiej Instytutu Badań Literackich, Polskiej Akademii Umiejętności ${ }^{22}$.

\section{Biblioteki i organizacje bibliotekarskie}

Biblioteki jako instytucje nauki i kultury, często podejmują się prac związanych $\mathrm{z}$ upowszechnianiem i propagowaniem wiedzy o książkach i bibliotekach. Czynnie włączają się w badania biograficzne dotyczące bibliotekarzy polskich. Najczęściej opracowania wychodzące $\mathrm{z}$ tych bibliotek przybliżają sylwetki lokalnych bibliotekarzy lub osób związanych z książką. Najwięcej informatorów o charakterze biograficznym poświęcono bibliotekarzom. Grupa ta jest szczególnie zasłużona dla badań biograficznych ludzi książki. Wiele informatorów o charakterze biograficznym powstaje w ramach statutowych prac bibliotek. Głównie odnosi się to do bibliotek publicznych, ale pojawiają się również odstępstwa od tej prawidłowości. W ramach tych prac tworzone są informatory biograficzne lub biografie zbiorowe różnych grup społecznych zarówno w środowisku lokalnym, jak i regionalnym. Analizując publikacje, w tworzenie których zaangażowani byli bibliotekarze, rozpocznijmy od stowarzyszeń.

\section{Stowarzyszenie Bibliotekarzy Polskich}

Szczególne znaczenie dla biografistyki księgoznawczej ma Stowarzyszenie Bibliotekarzy Polskich. Ta prawie stuletnia organizacja ceniona jest za ogromny wkład w badania biograficzne ludzi książki.

Początki SBP sięgają 1915 roku i związane są z Komisją Historii Książnic i Bibliotekoznawstwa przy Warszawskim Towarzystwie Miłośników Historii. W 1917 roku, jako efekt uchwały przygotowanej przez Komisję, Wydział Historii Książnic i Bibliotekoznawstwa został przekształcony w Związek Bibliotekarzy Polskich i pod tą nazwą funkcjonował do II wojny światowej ${ }^{23}$. Po wojnie, w 1945 roku Adam Łysakowski zarejestrował Związek Zawodowy Bibliotekarzy Polskich w Okręgowej Komisji Związków Zawodowych w Krakowie. W 1946 roku do Rejestru Stowarzyszeń i Związków Zawodowych został wpisany Związek Bibliotekarzy i Archiwistów Polskich - ogól-

\footnotetext{
22 J. Pirożyński, Drukarze dawnej Polski od XV do XVIII wieku. t. 3 cz. 2 Mazowsze z Podlasiem, „Roczniki Biblioteczne” R. 47, 2003, s. 214-215.

${ }^{23}$ E. Stefańczyk, 85 lat Stowarzyszenia Bibliotekarzy Polskich [w:] Adam Łysakowski bibliotekarz, bibliograf, bibliolog: materiały z sesji jubileuszowej, Warszawa 10 września 2002, Warszawa 2003, s. 121-122.
} 
nopolskie stowarzyszenie naukowe. Jednak już w 1953 roku, w Warszawie na obradach Walnego Zjazdu Delegatów ZBiAP, podjęto decyzję o przekształceniu go w Stowarzyszenie Bibliotekarzy Polskich ${ }^{24}$. Dziś SBP tworzy terenowe jednostki organizacyjne zwane okręgami, oddziałami oraz kołami, na zasadach określonych w statucie.

W statutowe cele SBP wpisane jest prowadzenie działalności wydawniczej, propagowanie wiedzy o roli książki, bibliotek i ośrodków informacji naukowej. Zadania te są realizowane przez bibliotekarzy i pracowników informacji naukowej m.in. w badaniach biograficznych.

Realizacja tych celów doskonale widoczna jest w pracach działającego od 1964 roku Zespołu Historyczno-Pamiętnikarskiego warszawskiego Oddziału Stowarzyszenia Bibliotekarzy Polskich. Związani z nim były m.in. Halina Chamerska, Alodia Kawecka-Gryczowa, Czesław Gutry, Helena Handelsman, Józefa Komecka, Ksawery Świerkowski, Hanna Zasadowa i Maria Lenartowicz. Zespół ten opracowuje biogramy osób, które w znaczący sposób przyczyniły się do rozwoju polskiego bibliotekarstwa oraz poprzez swoją pracę z książką i czytelnikiem wywarły wpływ na kulturę polską. Głównym jego zadaniem jest zachowanie pamięci o ludziach zasłużonych dla polskiego bibliotekarstwa. Niestety ze względu na brak środków zespół nie mógł opublikować zebranych materiałów. Dopiero po nawiązaniu współpracy z Ossolineum, udało się w 1974 roku wydać, w znanej serii popularnonaukowej Książki o Książce, publikację Twórcy nowoczesnego bibliotekarstwa polskiego ${ }^{25}$. Znaleźć w niej możemy wspomnienia o bibliotekarzach, pracujących głównie w Warszawie, którzy działali w okresie II Rzeczpospolitej i po II wojnie światowej. Kolejna publikacja Portrety bibliotekarzy polskich ${ }^{26}$ również była wynikiem prac zespołu i została wydana w serii Książki o Książce. Zawierała sylwetki zasłużonych twórców i organizatorów bibliotekarstwa polskiego.

Zespół Historyczno-Pamiętnikarski brał czynny udział w pracach związanych z biografistyką księgoznawczą. Od 1988 roku współpracował z redakcją II Suplementu Słownika pracowników książki polskiej, przygotowując biogramy wybitnych warszawskich bibliotekarzy. Włączył się również do prac nad Suplementem III ${ }^{27}$ tegoż słownika.

${ }^{24}$ E. Stefańczyk, Rola Stowarzyszenia Bibliotekarzy Polskich $w$ rozwoju bibliotekarstwa i unowocześnianiu bibliotek [w:] Książka, biblioteka, informacja w kręu kultury i edukacji, pod red. E.B. Zybert i D. Grabowskiej, Warszawa 2008, s. 208-209.

${ }_{25}$ Twórcy nowoczesnego bibliotekarstwa polskiego, red. B. Kocowski, Wrocław 1974.

${ }_{26}$ Portrety bibliotekarzy polskich, red. I. Morsztynkiewiczowa, Wrocław 1980.

${ }^{27}$ M. Dybaczewska, Z. Warczygłowa-Piotrowska, 45 lat działalności Zespołu Historyczno-Pamiętnikarskiego przy Zarządzie Oddziału Warszawskiego SBP, „Bibliotekarz” 2009, nr 10, s. 12-14. 
Prace Zespołu Historyczno-Pamiętnikarskiego od 1991 roku ukazują się w specjalnie stworzonej serii Bibliotekarze Polscy we Wspomnieniach Wspótczesnych. Dzięki różnorodnej tematyce poszczególne tomy stanowią bogate źródło danych biograficznych. W kolejnych tomach znalazły się sylwetki bibliotekarzy: uczestniczących w opracowaniu bibliografii ${ }^{28}$; zaangażowanych w prace społeczne ${ }^{29}$; prowadzących badania naukowe ${ }^{30}$; zasłużonych dla kształcenia i doskonalenia zawodowego bibliotekarzy ${ }^{31}$; wybitnych pod kątem pasji twórczej i zdolności organizatorskich ${ }^{32}$; pracujących z dziećmi bibliotekarek ${ }^{33}$; pracowników działów rękopisów ${ }^{34}$ oraz zbiorów specjalnych $^{35}$; zasłużonych Stowarzyszenia Bibliotekarzy Polskich ${ }^{36}$; pracowników bibliotek specjalnych ${ }^{37}$; bibliotekarzy warszawskich zmarłych w latach 1997$2007^{38}$ oraz teoretyków i praktyków polskiego bibliotekarstwa ${ }^{39}$. Sylwetki bibliotekarzy wymienianych $\mathrm{w}$ tych publikacjach stanowią wzór i przykład zaangażowania zawodowego bibliotekarzy.

\section{Korporacja Bibliotekarzy Wrocławskich}

Kolejne stowarzyszenie, zaangażowane $\mathrm{w}$ prace związane $\mathrm{z}$ biografistyką księgoznawczą, to działająca na terenie Wrocławia Korporacja Bibliotekarzy Wrocławskich, która wspólnie z Dolnośląską Biblioteką Pedagogiczną we Wrocławiu wydała dwie publikacje w serii $Z$ problemów bibliotek naukowych Wrocławia. Obie publikacje dotyczą środowiska wrocławskiego,

\footnotetext{
${ }^{28}$ Z warsztatu bibliografa, red. J. Cygańska, Warszawa 1991 (Bibliotekarze polscy we wspomnieniach współczesnych; 1)

${ }_{29}$ Z książka do ludzi, red. E. Pawlikowska, Warszawa 1992 (Bibliotekarze polscy...; 2)

${ }_{30}$ W kręgu nauki i bibliotek, red. S. Lorentz, Warszawa 1993 (Bibliotekarze polscy...; 3)

${ }_{31}$ Śladami edukacji bibliotekarskiej, red. H. Zasadowa, Warszawa 1995 (Bibliotekarze polscy...; 4)

32 Organizatorzy i inspiratorzy, red. D. Ostaszewska, W. Żukowska, Warszawa 1997 (Bibliotekarze polscy...; 5)

${ }^{33}$ Entuzjastki bibliotekarstwa dziecięcego, red. B. Białkowska, współudz. W. Wasilewska, Warszawa 1999 (Bibliotekarze polscy...; 6)

${ }^{34}$ Znawcy rękopisów, red. H. Zasadowa, M. Kocięcka, Warszawa 2002 (Bibliotekarze polscy...; 7)

${ }^{35}$ Kustosze zbiorów specjalnych, red. M. Kocięcka, H. Zasadowa, Warszawa 2004 (Bibliotekarze polscy...; 8)

${ }_{36}$ Zastużeni dla Stowarzyszenia Bibliotekarzy Polskich, red. A. Jopkiewicz, Warszawa 2005 (Bibliotekarze polscy...; 9)

${ }^{37}$ Bibliotekarze bibliotek specjalnych, red. M. Lenartowicz, Warszawa 2007 (Bibliotekarze polscy...;10)

${ }_{38}$ Bibliotekarze warszawscy zmarli w latach 1997-2007, red. M. Lenartowicz, Warszawa 2010 (Bibliotekarze polscy...; 11)

39 Teoretycy i praktycy polskiego bibliotekarstwa, red. M. Lenartowicz, Warszawa 2012 (Bibliotekarze polscy; 12)
} 
które żywo zareagowało na wydanie tomów poświęconych ludziom książki. Cieszący się dużą popularnością tom trzeci Wizerunek bibliotekarza ${ }^{40}$ oraz kolejny, siódmy tom Osobowości wrocławskiego bibliotekarstwa ${ }^{41}$, wydano pod redakcją Joanny Czyrek i Bożeny Górnej. W publikacjach przedstawione zostały biogramy cenionych wrocławskich bibliotekarzy. Przy większości znajdziemy bogatą bibliografię podmiotową. Korporacja jest stowarzyszeniem zrzeszającym, wyróżniających się pod względem rozwoju zawodowego i osobowościowego bibliotekarzy państwowych i prywatnych uczelni wrocławskich oraz innych instytucji naukowych Wrocławia ${ }^{42}$. Badania biograficzne bibliotekarzy wrocławskich są wpisane w statut stowarzyszenia i realizowane między innymi przez kolejne tomy cyklu $Z$ problemów bibliotek naukowych Wrocławia.

\section{Słownik bibliotekarzy wielkopolskich}

Wśród informatorów biograficznych o zasięgu regionalnym wyróżnia się Słownik bibliotekarzy wielkopolskich $1918-2000^{43}$ pod red. Franciszka Łozowskiego. Prace nad nim zapoczątkowano już w latach siedemdziesiątych, kiedy to okręgowe Stowarzyszenie Bibliotekarzy Polskich miasta Poznania i województwa poznańskiego, rozpoczęło zbieranie materiałów o zasłużonych bibliotekarzach regionu. Jednak to dopiero obchody osiemdziesięciolecia powstania i działalności SBP, zmotywowały działaczy stowarzyszenia do wznowienia i zintensyfikowania prac nad Słownikiem. Głównym kryterium wyboru osób, które mają zaistnieć na kartach informatora, było uwzględnienie najwybitniejszych przedstawicieli bibliotekarstwa w ówczesnym województwie poznańskim, czynnych zawodowo po I wojnie światowej do roku 2000 ${ }^{44}$. Wojewódzka Biblioteka Publiczna i Centrum Animacji Kultury w Poznaniu poszerza naszą wiedzę o Wielkopolsce i jej społeczności, o jej korzeniach i historycznych tradycjach. Znajdziemy tu biogramy najwybitniejszych przedstawicieli środowiska bibliotekarzy, którzy ukształtowali i współtworzyli polskie bibliotekarstwo.

\footnotetext{
${ }^{40}$ Wizerunek bibliotekarza, red. J. Czyrek, B. Górna, Wrocław 2006.

${ }^{41}$ Osobowości wrocławskiego bibliotekarstwa, red. J. Czyrek, B. Górna, Wrocław 2008.

42 Statut [w:] Korporacja Bibliotekarzy Wrocławskich, [online]. [dostęp: 29.05.2013]. Dostępny WWW: http://bibliotekarze.kbw.wroc.pl/Statut.htm

${ }_{43}$ Słownik bibliotekarzy wielkopolskich 1918-2000, red. F. Łozowski, Poznań 2001.

${ }^{44}$ Tamże, s. 7.
} 


\section{Główna Biblioteka Lekarska}

Główna Biblioteka Lekarska w Warszawie powstała 8 czerwca 1945 roku. Jej twórcą i pierwszym dyrektorem był prof. Stanisław Konopka (18961982). Powołując bibliotekę, zrealizował swoją przedwojenną koncepcję centralnej biblioteki państwa. Spełniała ona wszelkie funkcje nowoczesnej placówki bibliotecznej gromadzącej z założenia kompletną literaturę polską z zakresu medycyny i nauk pokrewnych, jak też ważniejsze pozycje literatury światowej. Nowo utworzona jednostka udostępniała je, upowszechniała oraz dokumentowała. Janusz Kapuścik, dyrektor Głównej Biblioteki Lekarskiej w latach 1981-1999 jest autorem publikacji dotyczącej osób różnych profesji, których łączy umiłowanie książki. Publikacje $W$ kręgu lekarzy, uczonych i bibliofilów ${ }^{45}$ oraz Wśród uczonych i miłośników książ$k i^{46}$ zostały wydane nakładem Głównej Biblioteki Lekarskiej, w serii Studia i Materiały. Autor przybliża sylwetki bohaterów książki, poprzez ważne szczegóły świadczące o ich stosunku do książki i roli, jaką odegrała w życiu wybitnych Polaków, szczególnie tych związanych ze środowiskiem lekarzy. Poza osobami, których zasługi dla rozwoju myśli teoretycznej i praktyki bibliotekarskiej są ogólnie znane, przedstawia życiorysy innych uczonych i literatów, często związanych ze środowiskiem medycznym, którzy zawodowo lub amatorsko zajmowali się książką ${ }^{47}$. Oprócz zaprezentowania sylwetek osób związanych z książką, w publikacji $W$ kręgu lekarzy, uczonych i bibliofilów przedstawiono również dzieje organizacji Polskiego Towarzystwa Higienicznego. Opracowania Janusza Kapuścika są przygotowane niezwykle rzetelnie, oparte na bogatych źródłach rękopiśmiennych i archiwalnych pochodzących głównie z zasobów Głównej Biblioteki Lekarskiej ${ }^{48}$. Wkład Głównej Biblioteki Lekarskiej w badania biograficzne ludzi związanych z książką jest niepodważalny - dzięki tym publikacjom mamy możliwość poznać sylwetki osób zawodowo związanych z medycyną, których pasją i miłością były książki.

\footnotetext{
${ }^{45}$ J. Kapuścik, W kręu lekarzy, uczonych i bibliofilów, Warszawa 1993.

${ }^{46}$ J. Kapuścik, Wśród uczonych i miłośników książki, Warszawa 1999.

47 D. Sieradzka, Janusz Kapuścik. W kręgu lekarzy, uczonych i bibliofilów, „Poradnik Bibliotekarza" 1995, nr 11/12, s. 39-40.

${ }^{48}$ H. Brzezińska-Stec, Wśród uczonych i miłośników książki, „Roczniki Biblioteczne” 2000, R. 44,2000 , s. $272-273$.
} 


\section{Biblioteki publiczne}

Kolejną grupą informatorów biograficznych, dotyczących ludzi książki, są publikacje opracowane przez zespoły poszczególnych bibliotek publicznych. Omówione zostaną jako grupa informatorów powstałych dzięki zaangażowaniu środowiska bibliotekarskiego w rozwój biografistyki księgoznawczej.

Publikacja Szli do ludzi $z$ ksią $k \mathrm{kq}^{49}$ zawiera informacje o bibliotekarzach pracujących w Opolu od czasów powojennych po rok 1960. Opracowanie ma formę wspomnień współpracowników lub samych bibliotekarzy, dotyczących organizacji biblioteki w powojennym mieście, którzy troszczyli się o rozwój kultury książki. Informator stworzony został przez Stowarzyszenie Bibliotekarzy Polskich oraz opolskie Koło Miejskie w Wojewódzkiej Bibliotece Publicznej im. Emanuela Smołki w Opolu. Wyjątkowość tego dzieła polega na tym, że część biogramów tworzona była na podstawie bezpośredniego kontaktu $\mathrm{z}$ bibliotekarzami lub ich rodzinami.

Publikacją o podobnym charakterze jest $Z$ pamięcia o nich: sylwetki bibliotekarzy ${ }^{50}$ pod red. Emilii Giery i Stefana Markowskiego. Pozycja została stworzona i opublikowana przez Wojewódzką Bibliotekę Publiczną im. Stanisława Grochowiaka w Lesznie. Pierwodruk ukazał się w 1984 roku, rok później praca została uzupełniona i wydana ponownie.

Kolejną publikacją autorstwa biblioteki jest Żyją w naszej pamięci: wspomnienia o pracownikach Biblioteki Publicznej m.st. Warszawy ${ }^{51}$, pod red. Janiny Jagielskiej i Teresy Jedynak, przygotowana w Bibliotece Publicznej m.st. Warszawy - Bibliotece Głównej Województwa Mazowieckiego. Informator ten jest hołdem dla tych, którzy budowali prestiż biblioteki poprzez swoją działalność zawodową i realizowanie pasji bibliotekarza. Wspomnienia te mają ocalić od zapomnienia sylwetki osób, które swoje życie zawodowe poświęciły „Koszykowej”. Przybliżone zostają sylwetki zarówno personelu merytorycznego, jak i technicznego, kierujących bibliotekami, jak i szeregowych pracowników. Dzięki lokalnemu zasięgowi publikacji oraz temu, że autorzy biogramów często znali osobiście bibliotekarzy i ich rodziny, teksty zostały opracowane bardzo szczegółowo, opisują cechy osobowości, upodobania i słabostki opisywanych bohaterów książki. Przybliża to sylwetki bibliotekarzy i pozwala ujrzeć, jakimi ludźmi byli. Inspiracją do

\footnotetext{
${ }^{49}$ Szli do ludzi z książką: sylwetki bibliotekarzy Opola, kom. red. H. Gąszczyńska, Opole 1987.

${ }^{50}$ Z pamięcią o nich: sylwetki bibliotekarzy, red. E. Giera, S. Markowski, Leszno 1985 [Wyd. 2 1986].

${ }^{51}$ Żyja w naszej pamięci: wspomnienia o pracownikach Biblioteki Publicznej m.st. Warszawy, red. i przedm. J. Jagielska, T. Jedynak, Warszawa 2006.
} 
stworzenia tej publikacji było stulecie działalności biblioteki, które obchodzono w maju 2007 roku. Jej celem było przypomnienie, że biblioteka to nie tylko pomieszczenia i zbiory, ale przede wszystkim tworzący ją ludzie - bibliotekarze, którzy swą pracą dla czytelnika nadają bibliotece charakter i przybliżają ją czytelnikowi ${ }^{52}$.

\section{Towarzystwa}

W badania biograficzne zaangażowanych jest również szereg regionalnych i lokalnych towarzystw naukowych. Instytucje te zajmują się badaniem życia i działalności swoich członków. Ich osiągnięcia znalazły swoje miejsce $\mathrm{w}$ informatorach o charakterze biograficznym.

\section{Kujawsko-Pomorskie Towarzystwo Kulturalne}

Kujawsko-Pomorskie Towarzystwo Kulturalne istniało w latach 19612008. Zajmowało się promocją kultury regionalnej, popularyzowaniem wiedzy o regionie, rozwijaniem różnych form twórczości amatorskiej oraz pielęgnowaniem kultury ludowej i folkloru. Najważniejszą dziedziną działalności towarzystwa były publikacje książkowe (kilkaset pozycji). KPTK specjalizowało się w monografiach miast i regionów oraz książkach o ludziach zasłużonych dla lokalnych społeczności. Jedną z tych pozycji była publikacja W służbie książki i prasy polskiej: Bydgoszcz XIX-XX wiek w $^{53}$ autorstwa Józefa Podgórecznego, która poprzez biogramy księgarzy, drukarzy i ludzi pokrewnych zawodów, przedstawia dzieje księgarstwa polskiego, szczególnie upowszechniania książki polskiej w okresie zaboru pruskiego. Wszystkie biogramy oparte były na materiałach źródłowych, prasowych, przekazach ustnych i rodzinnych kronikach.

\section{Lubelskie Towarzystwo Miłośników Książki}

Kolejne zaangażowane w badania biograficzne towarzystwo zostało założone 18 czerwca 1926 roku na zebraniu zorganizowanym dla uczczenia zasług bibliofilskich Hieronima Łopacińskiego. Jego pierwszym prezesem był ks. dr Ludwik Zalewski, bibliotekarz oraz profesor Seminarium Duchownego w Lublinie. Celem Towarzystwa było szerzenie i popularyzacja książki poprzez prowadzenie działalności w kierunku badawczo-naukowym i wydawniczym. Wynikiem tych badań są m.in. dwa opracowania

52 Tamże, s. 7-9.

53 J. Podgóreczny, W służbie książki i prasy polskiej: Bydgoszcz XIX-XX wiek, Bydgoszcz 1978. 
zatytułowane: Sylwetki bibliofilów lubelskich ${ }^{54}$ pod red. Marii i Henryka Gawareckich, przedstawiające biogramy członków tego towarzystwa oraz publikacja Kawalerowie Orderu Białego Kruka ze Słonecznikiem ${ }^{55}$ w opracowaniu Zbigniewa Jóźwika, która zawiera biogramy członków Lubelskiego Towarzystwa Miłośników Książki, odznaczonych „Orderem Białego Kruka ze Słonecznikiem”. Oznaczenie to przyznawane jest od 1976 roku, a zostało ustanowione z okazji 50-lecia towarzystwa. Przyznawane jest za wybitną działalność bibliofilską. Jego nazwa wzorowana jest na wygasłym krakowskim odznaczeniu Orderze Białego Kruka. Nazwa „Order Białego Kruka ze Słonecznikiem - Signum Albi Corvi cum Heliantho dla Lublina” była nawiązaniem do pierwszego znanego druku lubelskiego, wydanego w 1630 roku w języku polskim Słonecznik albo porównanie woli ludzkiej z wola Boża Remiasza Dreceliusza ${ }^{56}$. Publikacje te skupiają się głównie na przybliżeniu sylwetek osób zasłużonych dla Lubelskiego Towarzystwa Miłośników Książki.

\section{Towarzystwo Przyjaciół Książki}

Informatorem przybliżającym sylwetki miłośników książek jest Poczet bibliofilów ślaskich ${ }^{57}$, który przedstawia członków Śląskiego Oddziału Towarzystwa Przyjaciół Książki. Jest to jedynie rejestr wydany z okazji jubileuszu 30-lecia oddziału. Zawiera on imię i nazwisko, datę wstąpienia do Towarzystwa Przyjaciół Książki oraz zawód w momencie wpisania do rejestru. Nie są to biogramy, ale dzięki temu wydawnictwu możliwe jest poznanie członków tego towarzystwa.

\section{Stowarzyszenie Księgarzy Polskich}

Kolejnym informatorem biograficznym, stworzonym przez instytucję jest Klub Miłośników Historii Ksieggarstwa: sylwetki członków ${ }^{58}$, wydany przez Stowarzyszenie Księgarzy Polskich. Klub istnieje od 1958 roku. Celem publikacji jest przedstawienie 93 sylwetek członków tego klubu zarówno tych żyjących, jak i zmarłych, od momentu jego powstania do 2002 roku $^{59}$. $\mathrm{W}$ informatorze znajdziemy historię i kronikę klubu wraz z zasadami funk-

${ }^{54}$ J. Podgóreczny, W służbie książki i prasy polskiej: Bydgoszcz XIX-XX wiek, Bydgoszcz 1978.

55 Kawalerowie Orderu Białego Kruka ze Słonecznikiem, oprac. Z. Jóźwik, Lublin 1999.

${ }^{56}$ Z. Jóźwik, Osiemdziesiąt lat Lubelskiego Towarzystwa Miłośników Książki 1926-2006, s. 80.

57 Poczet bibliofilów śląskich, red. Z. P. Szandar, Katowice 1998.

${ }^{58}$ F. Trzaska, Klub Miłośników Historii Ksieggarstwa: sylwetki członków, Warszawa 2000.

${ }_{59}$ F. Trzaska, Klub Miłośników Historii Księgarstwa: sylwetki członków, „Wiadomości Księgarskie" 2002, nr 4, s. 27. 
cjonowania. Najważniejsze z nich to: zachowanie tradycji zawodowej księgarzy, czuwanie nad godnością zawodu, dbałość o kształcenie zawodowe i młode kadry księgarzy, wprowadzanie postępu i kultywowanie kontaktów kulturalnych i towarzyskich wśród członków. Informator ten przypomina postacie szczególnie zasłużone dla środowiska księgarskiego.

\section{Zakończenie}

Wymienione powyżej instytucje nauki i kultury, scharakteryzowane na tle informatorów biograficznych o ludziach książki różnych zawodów, wykazują duże zainteresowanie badaniami biograficznymi. Wszystkie te organizacje współpracowały przy tworzeniu informatorów. Szczególnie zaangażowani w badania biograficzne swojej grupy zawodowej są bibliotekarze oraz tworzone przez nich stowarzyszenia, w tym przede wszystkim Stowarzyszenie Bibliotekarzy Polskich, które miało udział w opublikowaniu wielu informatorów o charakterze biograficznym. O popularności badań biograficznych świadczą kolejne wydania, nowe tomy i żywe zainteresowanie środowiska tymi publikacjami, co widoczne jest $w$ recenzjach pojawiających się w prasie fachowej. Dzięki czynnemu udziałowi środowiska, kolejne tomy i wydania są coraz lepiej przygotowane, a wszelkie niedociągnięcia eliminowane.

W przypadku pozostałych instytucji związanych z kulturą książki, takich jak: Kujawsko-Pomorskie Towarzystwo Kulturalne, Lubelskie Towarzystwo Miłośników Książki, Towarzystwo Przyjaciół Książki oraz Stowarzyszenie Księgarzy Polskich, widzimy wyraźną troskę o zachowanie pamięci o członkach tych organizacji. Dzięki tym publikacjom pamięć o nich przetrwa kolejne pokolenia. 


\section{Abstract \\ The institutions of science and culture involvement in the development of Polish bibliological biography}

The development of the Polish bibliological biography is best evidenced by the number of biographical directories and collective biographies of book people. In the analysis of publications from the twentieth and twenty-first centuries, the emphasis was placed on the involvement of cultural and scientific institutions in the creation of those publications. In the article, the author presents the contributions of particular institutions to the development of bibliological biographies. In particular, the following institutions are involved in this process: the Słownik pracowników ksiażki polskiej Laboratory by the Chair of Library and Information Science at the University of Lodz; the Old Polish Bibliography Laboratory at the Institute of Literary Research of the Polish Academy of Sciences; Polish Librarians' Association; Wroclaw Librarians' Corporation; Kujawy and Pomerania Cultural Society; Lublin Society of Book Lovers; and numerous libraries. The aforementioned institutions were presented against the background of biographical directories which they helped create. 